\title{
New species of Iconella Jurilj (Bacillariophyta) from tropical areas of China
}

\author{
Yan LiU ${ }^{1}$, Ziyi Jiang ${ }^{1}$, John Patrick Kociolek ${ }^{2}$, Xinxin Lu $^{1} \&$ Yawen FAN ${ }^{*}$ \\ ${ }^{1}$ College of Life Science and Technology, Harbin Normal University, Harbin, 150025, China. *Corresponding \\ author e-mail: Yawen Fan:fanyaw@163.com \\ ${ }^{2}$ Museum of Natural History and Department of Ecology and Evolutionary Biology, University of Colorado, \\ Boulder, CO 80309, U. S. A.
}

\begin{abstract}
Three distinctive species of the diatom genus Iconella Jurilj were described from tropical areas of China. These new species all have the canal raphe extending around valve margins, keel raised off the valve surface forming wings, fenestrae obvious and alar canals that are uniformly porous. Together these features suggest these species should be assigned to the newly re-established genus Iconella. Here we describe Iconella shiwana Yan Liu, Ziyi Jiang et Kociolek sp. nov., Iconella pseudoconstricta Yan Liu, Ziyi Jiang et Kociolek sp. nov. and Iconella uniformis Yan Liu, Ziyi Jiang et Kociolek sp. nov., all described on the basis of light and scanning electron microscope observations from material collected from Hainan and Southern Guangxi Provinces. Iconella shiwana differs from other taxa by its isopolar valves and broadly round apices, tri- to quadriseriate short striae and large elliptical hyaline area in the valve center. I. pseudoconstricta is also isopolar, but it has acute ends and a constricted valve center. I. uniformis has heteropolar valves with a broadly rounded head pole and acute foot pole, a large spine is present near the head pole, and hook-like helictoglossae present at the foot pole. Our previous studies in tropical areas in China showed the diatom flora includes endemic taxa, although additional investigations are needed to explore and describe the abundant biodiversity there.
\end{abstract}

Key words: Iconella, new species, tropical areas, China

\section{INTRODUCTION}

The genus Iconella Jurilj (JURILJ 1949) was re-established by RUCK et al. (2016) based on morphological and molecular research on the Surirellales and Rhopalodiales (RUCK et al. 2016). According to RUCK et al. (2016)'s new classification, the well-known Surirella Turpin (TURPIN 1828) was split into two genera, Surirella and Iconella. The newly-circumscribed "Surirella" contains the "Pinnatae" group of Surirella species, exemplified by taxa such as S. striatula Turpin (TURPIN 1828) and S. sella Hustedt (HuSTEDT 1925) as well as the genus Cymatopleura Smith (SMITH 1851). Iconella was composed of the "Robustae" group of Surirella, "Robusti" group of Campylodiscus Ehrenberg ex Kützing (KüTzING 1844) and the genus Stenopterobia Brébisson ex Van Heurck (VAn Heurck 1896). The diagnostic morphological characters of Iconella were described by JAHN et al. (2017) as having a "raphe canal [that] rises above the valve face and mantle and has alar canals with fenestral openings occluded by fenestral bars with internally rimmed pores." Changes in nomenclature and new combinations needed to adhere to the new taxonomic scheme proposed by RUCK et al. (2016), have been proposed by JAHN et al.
(2017) and KAPUSTIN \& KULIKOvSKIY (2018).

Tropical areas are renown for harboring high levels of biodiversity of freshwater diatoms, with numerous new and endemic species reported (e.g. Metzeltin \& LANGE-BERTALOT 1998). Surirella was also found have high diversity in tropical areas with many new species were discovered from different continents, such as Asia (Hustedt 1937-1939; BrambUrGer et al. 2006; KARTHICK et al. 2012), Africa (COCQUYT \& JAHN 2005a, b, 2007a,b,c; CoCQuYT \& KUSBer 2010; CoCQuYT \& TAYLOR 2015), South America (SALA et al. 2013), and Oceania (VyVERMAN 1991).

The genus Surirella was first reported from China by MereschKowsKy (1906), and he described one new Surirella species (Surirella tibetica Mereschkowsky), which was later made into a new combination (as Surirella helvetica var. tibetica (Mereschkowsky) Cleve-Euler (Cleve-Euler 1952). Although several reports have focused on Surirella from China (YANG 1999; ZHU \& CHen 2000; You et al. 2011; WANG 2018; LiU et al. 2019), only 102 taxa have been reported from China (unpublished data). Just over $10 \%$ of the Surirella taxa reported from China have been newly described, as 12 new species have been described from China (Table 
1). Most of these new Surirella taxa were described by SKVORTZOW $(1927 ; 1928 ; 1929 a, b ; 1930 ; 1976)$ based on his extensive studies on the freshwater diatoms of China. The Surirella records from tropical regions in China are few, with only 4 species recorded previously from Hainan Province (WANG 2018). Compared with the names reported worldwide (more than 2000 names in KocioleK et al. 2020), the diatoms of Surirella sensu lato are still poorly known in China.

During our investigation of diatoms from tropical areas of China, samples from Hainan and Southern Guangxi were collected, and three new species of Iconella were discovered. In this paper, the morphological characters were described based on LM and SEM observations for these 3 new species.

\section{Materials ANd Methods}

In 2014 and 2018 collections of diatoms were taken from tropical areas of China from Hainan Province and Southern Guangxi Province, which are located in the tropical monsoon climatic zone, exhibiting high temperature and humidity.

Samples were fixed with $4 \%$ formaldehyde in the field. Water temperature, $\mathrm{pH}$ (KL-009III pen-based high-precision $\mathrm{pH}$ meter) and conductivity (DDB-11A Portable digital conductivity meter) were measured during the collection time. Samples contained the new species are listed at Table 2.

Materials were boiled with $\mathrm{HNO}_{3}$, then washed and settled using distilled water to remove all the organic matter and nitric acid, until the $\mathrm{pH}$ was neutral. For light microscope (LM) observations, cleaned diatoms were mounted with Naphrax. Permanent slides were examined with a Zeiss Imager A2 microscope equipped with a digital camera (AxioCam MRc 5) and observed with DIC (differential interference contrast) optics (Zeiss, Jena, Germany at Harbin Normal University), and Olympus BX 51 microscope with DIC optics, equipped with a Olympus DP 71 camera (Olympus, Tokyo, Japan at the University of Colorado, Boulder). For scanning electron microscope (SEM) observations, cleaned material was airdried and coated with gold-palladium, and observations made with a Hitachi S-4800 field emission SEM (Hitachi, Tokyo, Japan at Harbin Normal University) at an operating voltage of $15 \mathrm{kv}$. Diatom images were compiled with Photoshop 7.0. Terminology follows that of RUCK \& KocioleK et al. (2004), Bramburger et al. (2006) and JAHN et al. (2017). Samples, cleaned material and permanent slides are all archived at the Key Laboratory of Biodiversity of Aquatic Organisms, Harbin Normal University.

\section{RESULTS}

Iconella shiwana Yan Liu, Ziyi Jiang et Kociolek sp. nov. Figs (1-10, LM; 11-20, SEM)

LM observations: Valves isopolar or slightly heteropolar, linear, with broadly rounded poles. Middle portion of the valve slightly constricted in larger valves, nearly parallel in smaller valves. Length 32.5-54.5 $\mu \mathrm{m}$, breadth 11.5-12.1 $\mu \mathrm{m}$, length to breadth ratio 2.8-4.5: $1(\mathrm{n}=30)$. Fibulae distinct, 6-7/10 $\mu \mathrm{m}$. Porcae nearly parallel in the valve center, becoming radiate toward the apices. Axial area narrow and linear, interrupting the porcae.

SEM observations: Externally, raphe canal extends around the periphery of valve, discontinous at both apices, curved towards the mantle (Fig. 12). Keel elevated from the valve surface, fenestrae well-developed, containing 2-3 fenestral bars (Fig. 13). On the alar canals, striae are short, nearly $1 / 3$ length of the half valve, triseriate (Fig. 14). Porcae smooth, without areolae (Figs 13-14). In the depressions between porcae, striae are

Table 1. Surirella taxa which were originally reported from China.

\begin{tabular}{|c|c|}
\hline Species name & Literature \\
\hline Surirella angusta var. amoyensis Skvortsov & SKVORTZOW 1929 \\
\hline Surirella didyma var. hinganica Skvortsov & SKVORTZOW 1976 \\
\hline Surirella fukiensis Skvortsov & SKVORTZOW 1930 \\
\hline Surirella helvetica var. tibetica (Mereschkowsky) Cleve-Euler & Cleve-Euler 1951 \\
\hline Surirella hinganica Skvortsov & SKVORTZOW 1976 \\
\hline Surirella ovalis [var. minuta] f. tientsinensis Skvortzow & SKVORTZOW 1930 \\
\hline Surirella ovata f. curta Skvortsov & SKVORTZOW 1930 \\
\hline Surirella ovata f. mongolica Skvortsov & SKVORTZOW 1930 \\
\hline Surirella robusta var. manschurica Skvortsov & SKVORTZOW 1928 \\
\hline Surirella saxonica var. sinica Skvortsov & SKVORTZOW 1930 \\
\hline Surirella tenera var. hinganica Skvortsov & SKVORTZOW 1976 \\
\hline Surirella tientsinensis Skvortsov & SKVORTZOW 1927 \\
\hline
\end{tabular}


long, extending to the axial area, uniseriate or biseriate (Figs 13-15). Areolae on the valve surface are covered by tiny siliceous granules (Fig. 15). Axial area smooth, without areolae or spines (Figs 11, 14). Internally, raphe discontinuous at both apices (Figs 17-18), helictoglossae are not expanded, a raised nodule-like structure formed between two distal raphe ends (Figs 17-18). Striae short internally, forming a large elliptical hyaline area in the valve center (Fig. 16). Striae mostly present on both valve and mantle sides of portulae (Fig. 19), 3-4 striae per portula, each stria composed by 3-4 rows of areolae (Figs 17, 18, 20). Several irregular striae occur on the fibulae, bi- to triseriate (Fig. 20).

Holotype: HANU! Individual in slide THHN2018004, here illustrated as Fig. 1.

Isotype: COLO! Kociolek Collection (University of Colorado, Boulder, U.S.A.), slide no. 650046.

Type locality: Small pond near the river, Shiwan Mts. National Forest Park., Guangxi Zhuang Autonomous Region. Coll. Y. Liu \& X.X. Lu May 2018.

Etymology: This species is named for its type locality. Remarks: Only known from the type locality.

Iconella pseudoconstricta Yan Liu, Ziyi Jiang et Kociolek sp. nov. Figs (21-32, LM; 33-42, SEM)

LM observations: Valves isopolar, linear, tapered to rounded apices, valve middle slightly constricted. Length $25-41 \mu \mathrm{m}$, breadth at mid-valve 5-8 $\mu \mathrm{m}$, breadth at widest portion $7-10 \mu \mathrm{m}$, length to breadth ratio is 5 : $1(n=30)$. Fibulae $7-8 / 10 \mu \mathrm{m}$. Axial area very narrow, linear. Porcae nearly parallel in the middle and slightly radiate towards the apices. Striae indistinct.

SEM observations: Externally, raphe canal runs along the periphery of the valve margin, discontinuous at both apices (Figs 34-35), distal raphe ends straight and flat (Figs 34-35). Keel elevated above the valve face, fenestrae well-developed. Each fenestra contains 1-2 fenestral bars (Fig. 36). Striae extending into the axial area, biseriate (Fig. 37). Areolar openings round and occluded (Fig. 37). Internally, raphe discontinuous at both apices, helictoglossae small and flat (Figs 39-40).
Striae occur on both valve face and mantle, interrupted by the axial area in the middle (Fig. 42), areolar openings small and round, unoccluded and without rims (Fig. 41).

Holotype: HANU! Individual in slide THHN2014017, here illustrated as Fig. 21.

Isotype: COLO! Kociolek Collection (University of Colorado, Boulder, U.S.A.), slide no. 650047.

Type locality: Stream. Wuzhi Mountains. Hainan Province, Coll. Y. Liu \& X.X. Lu July 2014.

Etymology: This species is named for its central constriction.

Remarks: This species also found from samples THHN2014162 and THGX2014267.

Iconella uniformis Yan Liu, Ziyi Jiang et Kociolek sp. nov. (Figs 43-61)

LM observation: Valves heteropolar, lanceolate, head pole broadly round, foot pole narrowly rounded. Length 71.6-94.4 $\mu \mathrm{m}$, breadth 30.4-38.0 $\mu \mathrm{m}$, length to breadth ratio is 2.4-2.5: $1(\mathrm{n}=30)$. Fibulae $18-22 / 100 \mu \mathrm{m}$. Axial area lanceolate, wider in the center, narrower toward the apices. A distinct spine is visible at the end of axial area near the head pole. Porcae slightly radiate along the whole valve. Striae indistinct.

SEM observations: Externally, raphe canal runs along the periphery of the margin, discontinuous at both apices. At head pole, distal raphe ends straight, slightly raised, tooth-like in appearance, positioned on the mantle of headpole (Fig. 53). Keel elevated off of the valve face. Fenestrae well-developed, each containing 4-5 fenestral bars. Striae continuous across the axial area, uni- to biseriate (Fig. 55). Numerous granules scattered in the depression between porcae (Figs 53-55). One robust spine present at the headpole of axial area (Fig. 54). Several needle-shaped small spines occur on some fenestral bars. Internally, raphe continuous at the headpole (Fig. 58), discontinuous at the footpole, forming two large hookshaped helictoglossae (Fig. 59). Axial area has a lanceolate depression (Fig. 57). Striae uni- to biseriate, continuous across the axial area (Fig. 60). Areolar openings small, round and rimmed (Fig. 61).

Table 2. Sampling information for new species in this research.

\begin{tabular}{llllll}
\hline Sample No. & Locality & Habitat & pH & $\begin{array}{l}\text { Conductivity } \\
\left.(\boldsymbol{\mu S . c m})^{-1}\right)\end{array}$ & WT $\left({ }^{\circ} \mathbf{C}\right)$ \\
\hline THHN2014017 & Wuzhi Mts, Hainan Province & Stream & 4.78 & 20 & 23 \\
THHN2014078 & Diaoluo Mts. Hainan Province & Stream & 7.52 & 120 & 26.4 \\
THHN2014153 & Jianfengling Mts. Hainan Province & Stream & 6.98 & 70 & 26.3 \\
THHN2014162 & Jianfengling Mts. Hainan Province & Lake & 6.98 & 50 & 24.8 \\
THGX2014267 & Fangchengjiang & Wet-wall & 4.78 & - & 26.9 \\
THGX2018004 & Shiwan Mts. Guangxi & Epiphyton on & 4.49 & 15.31 & - \\
\hline
\end{tabular}



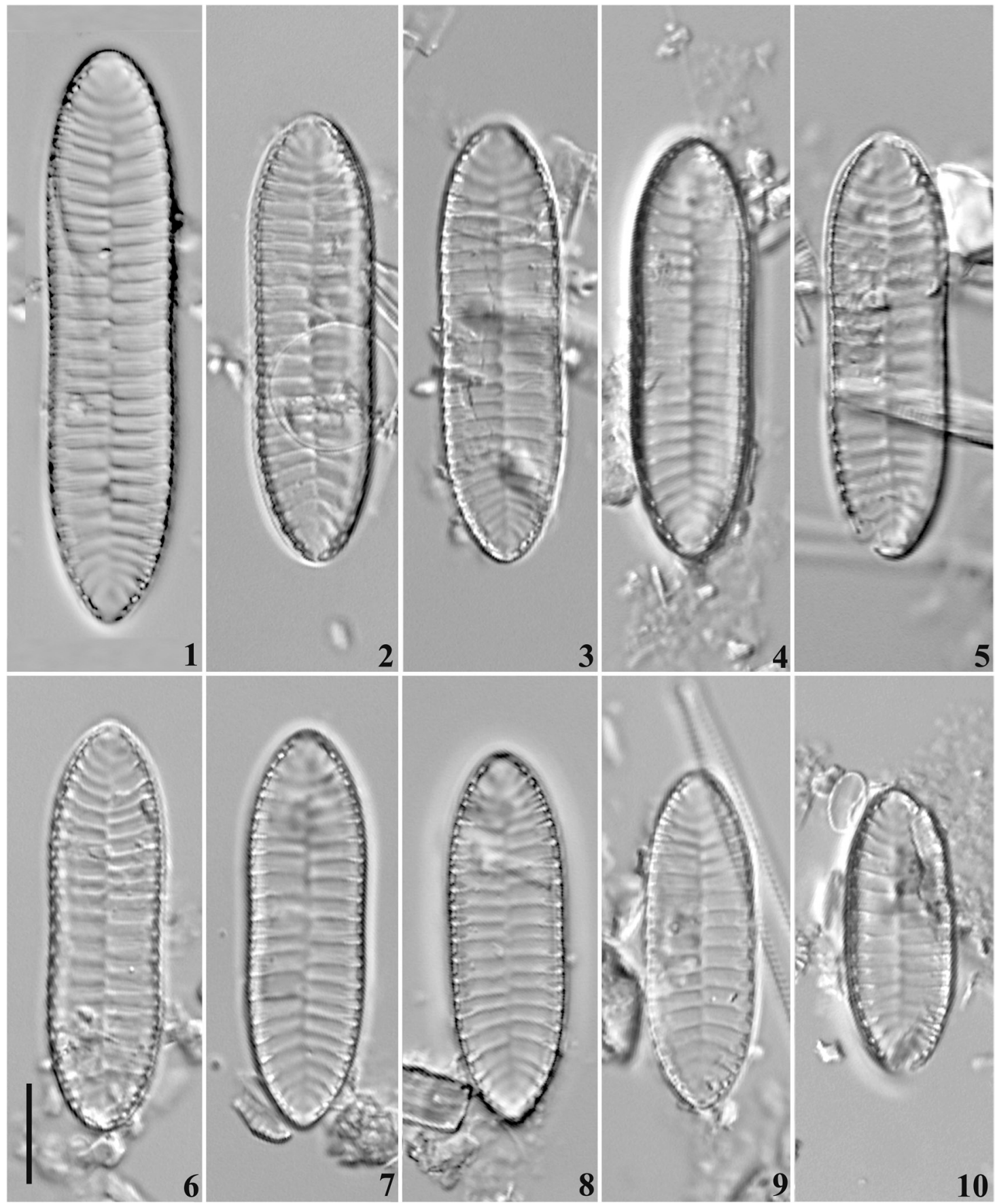

Figs 1-10. Iconella shiwana Yan Liu, Ziyi Jiang et Kociolek, LM pictures, valve view showing size variation. Fig. 1 is of the holotype. Scale bar $10 \mu \mathrm{m}$.

Holotype: HANU! Individual in slide THHN2014078, here illustrated as Fig. 44.

Isotype: COLO! Kociolek Collection (University of Colorado, Boulder, U.S.A.), slide no. 650048.

Type locality: Stream. Diaoluo Mountains. Hainan Province, Coll. Y. Liu \& X.X. Lu July 2014.

Etymology: This species is named for its large, hookshaped helictoglossae.

Remarks: This species was also found from sample THHN2014153.

\section{Discussion}

All 3 new species considered here possess features that would support their assignment to the genus Iconella, including canal raphe extending around the whole valve margin, keel raised off the valve surface, presence of wings, fenestrae obvious, and uniformly porous alar canals. However, the two isopolar species, I. shiwana and I. pseudoconstricta have discontinuous raphe ends at both apices, which were illustrated as the character of "Pinnatae" group of Surirella (JAHN et al. 2017). 

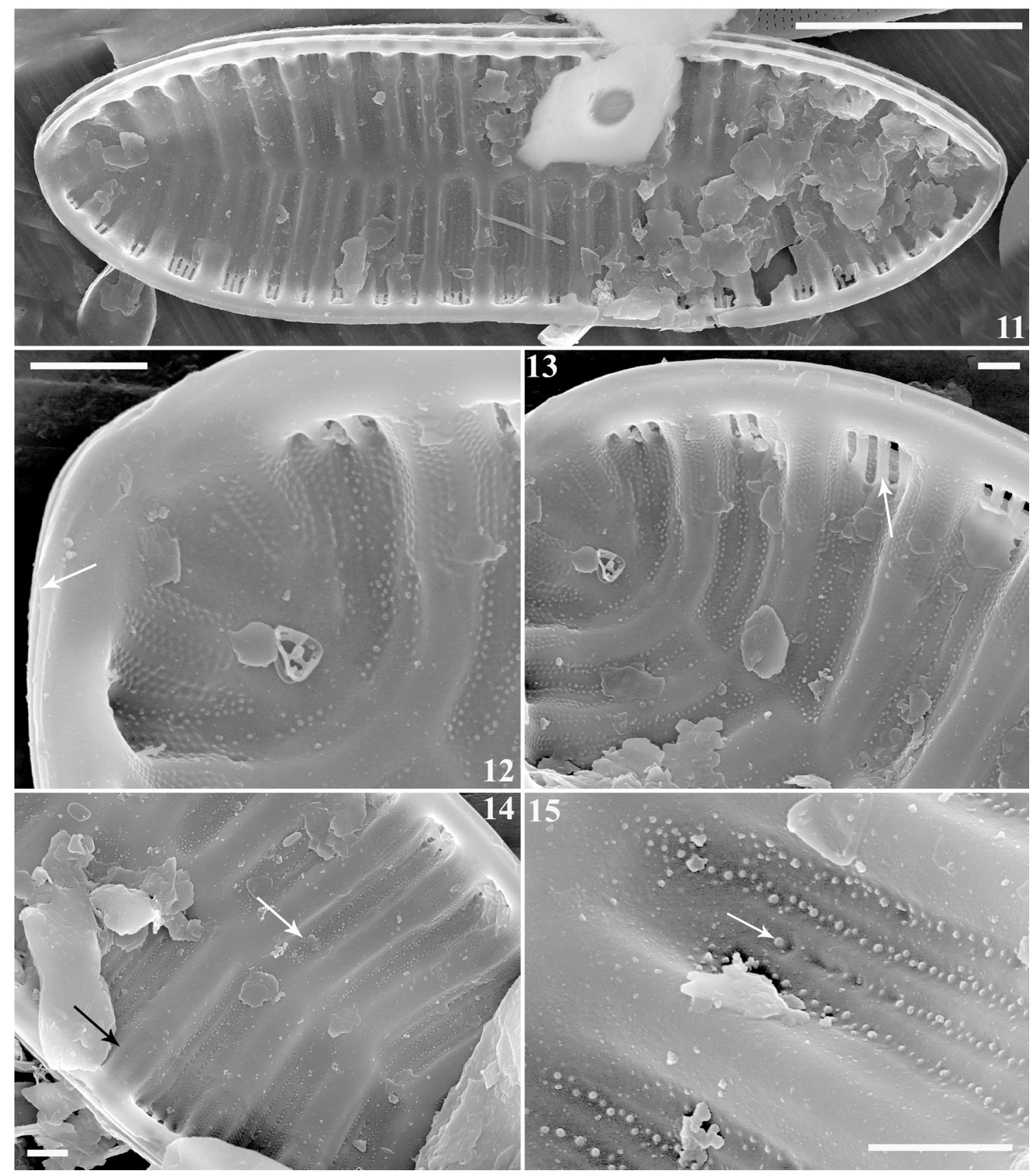

Figs 11-15. Iconella shiwana Yan Liu, Ziyi Jiang et Kociolek, SEM pictures, external views: (11) whole valve; (12) apex of the valve, showing the hooked distal raphe end (white arrow); (13) magnification of valve margin, showing the fenestral bars (white arrow); (14) valve face, showing the normal length striae (white arrow) and short striae at the porcae (black arrow); (15) striae showing areolae opening covered by the tiny silica granules. Scale bar $10 \mu \mathrm{m}(11), 1 \mu \mathrm{m}(12-15)$.

Additionally, these two taxa also do not have rimmed pores internally, a feature also missing in Surirella congolensis Cocquyt et Taylor (COCQUYT \& TAYLOR 2015) and Surirella leyana Bramburger et Hamilton in BRAMBURGER et al. (2006) (KARTHICK et al. 2012), which do not fit the illustrations for Iconella in JAHN et al. (2017). The number of taxa previously assigned to the genus Surirella sensu lato number over 1800 (KocioleK et al. 2020), yet fewer than $130(7.2 \%)$ have been investigated with SEM (Gaul et al. 1993; Henderson \& Reimer 2003). As suggested by the distribution of characters in the four taxa cited above, it is possible that features suggested to diagnose genera in the phylogeny of RUCK et al. (2016), and thus the recognition of taxa, may be in further need of review.

In terms of the distinctions of the three taxa considered herein, and their separation from similar forms, Iconella shiwana, is only known from Shiwan Mountains in Guangxi Zhuang Autonomous Region, an area with some very unique diatom taxa, including the genus Sinoperonia Kociolek et al. in LiU et al. (2018) and new species of Neidium Pfitzer (Pfitzer 1871) in 


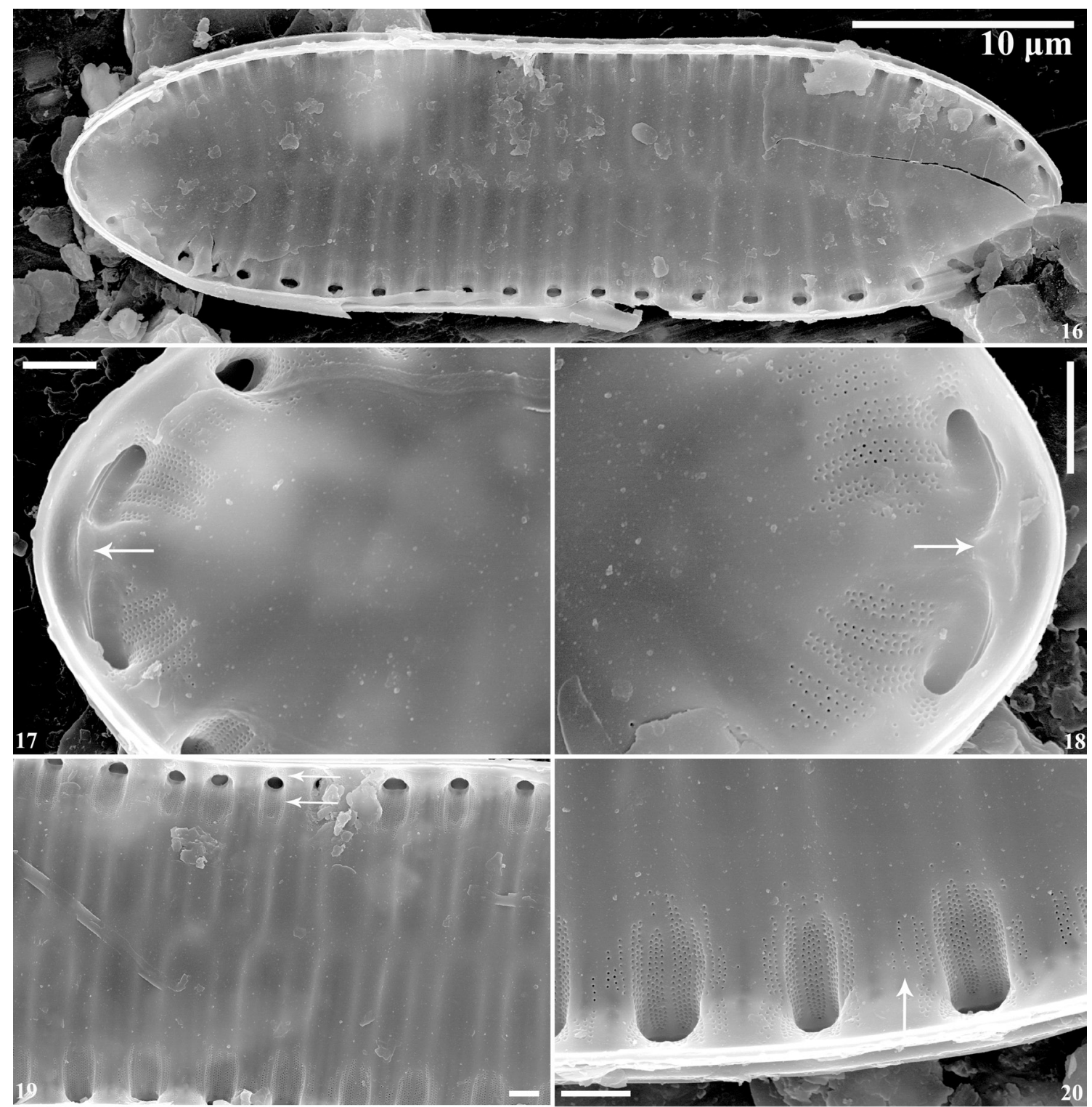

Figs 16-20. Iconella shiwana Yan Liu, Ziyi Jiang et Kociolek, SEM pictures, internal views: (16) whole valve, showing the elliptical hyaline area in the center; (17-18) apices of the same valve, showing the discontinuous raphe ends, and a nodule structure between the two distal raphe ends (white arrow); (19) valve face showing striae on both valve and mantle sides (white arrows) of the portulae; (20) scattered striae on fibulae (white arrow). Scale bar $10 \mu \mathrm{m}(16), 1 \mu \mathrm{m}(17-20)$.

Liu et al. (2020). I. shiwana differs from other taxa by the isopolar valve and linear outline with broadly round apices. SEM observations also showed very distinctive character of the striae internally. Most Iconella or Surirella species have the same organization of striae both externally and internally, but I. shiwana has tri- to quadriseriate, short striae internally, forming a large, elliptical hyaline area in the valve center but externally this species has striae that are long, extending to the axial area, and being uniseriate or biseriate. Helictoglossae are distinct, a fused nodule structure is present between the two raphe ends.

Iconella pseudoconstricta differs from I. shiwana by its acutely-rounded apices and more slender valves. It also resembles Surirella rafaelii Ramirez \& Sala in SALA et al. (2013), which is also reported from a tropical area, but $S$. rafaelii can easily be separated from I. pseudoconstricta by its large valve, central ridge and tendrils at the base of fenestrae.

Iconella uniformis resembles the cosmopolitan species Surirella splendida (Ehrenberg) Kützing (KüTZING 1844), the difference between these two species is that I. uniformis is smaller and has a spine at the end of axial area near headpole. Our specimens also resemble S. splendidoides Hustedt (Hustedt 1965) as illustrated in Metzeltin \& Lange-Bertalot (1998, Taf. 209: 1-2), but the type specimens of Hustedt's taxon does not have a spine at the central area, as illustrated in SimONSEN (1987, pl. 757: 4-5). A very distinctive feature of I. uniformis is the hook-like helictoglossae at the foot pole. The helictoglossae are usually overlooked by researchers (e.g.: Krammer \& Lange-Bertalot 1997; Ruck \& 


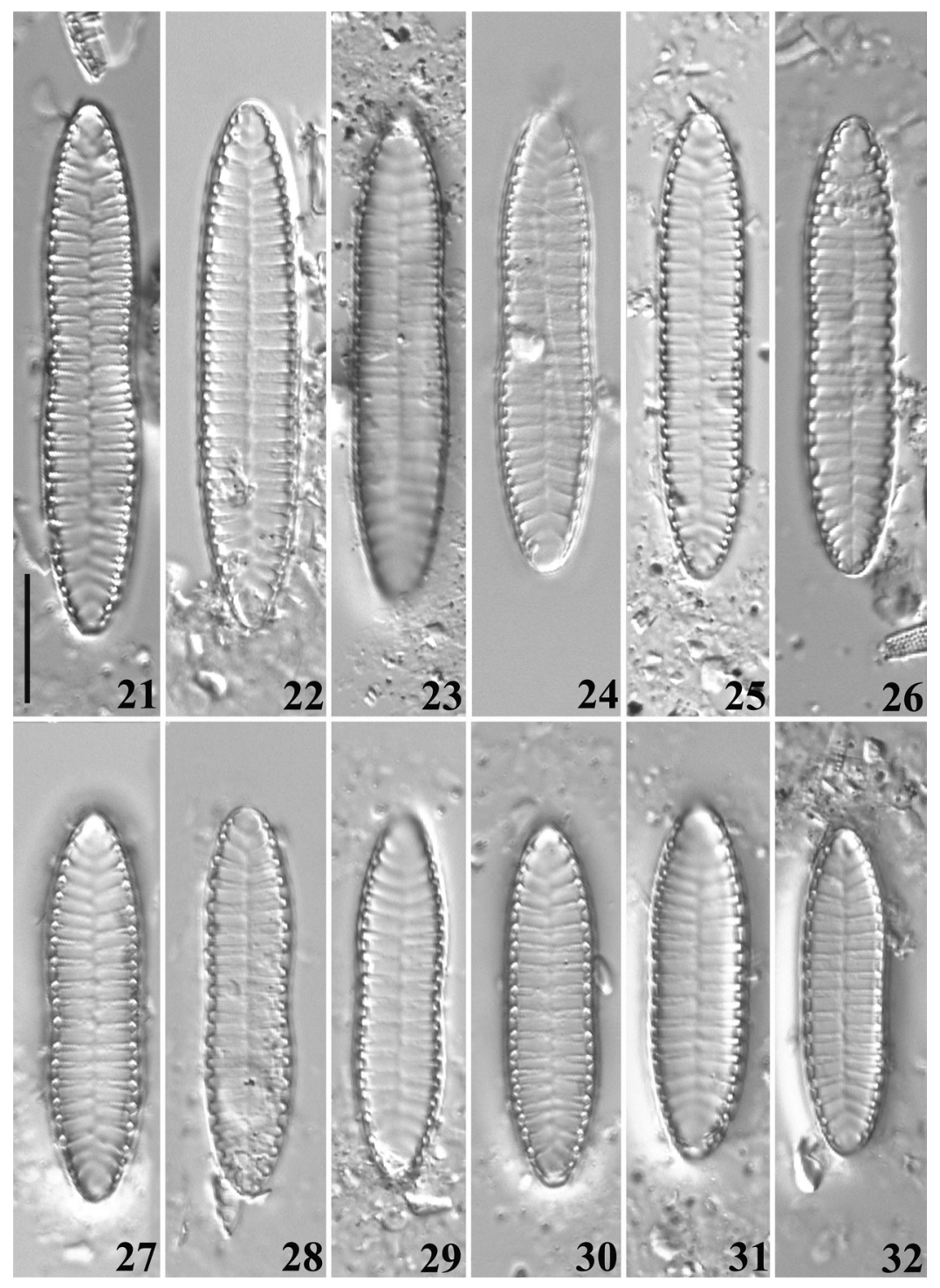

Figs 21-32. Iconella pseudoconstricta Yan Liu, Ziyi Jiang et Kociolek, LM pictures, valve views showing size variation: (21) is of the holotype. Scale bar $10 \mu \mathrm{m}$.

KocioLeK 2004), and the various morphologies of the structure of helictoglossae in Iconella or Surirella are poorly documented for new species, even in more recent treatments (e.g.: ENGLish \& PotaPova 2011; Blanco et al. 2012; VAN DE VIJVER et al. 2013; BRINDLE et al. 2018). RUCK \& KoCIOLEK (2004) described helictoglossae in S. robusta Ehrenberg (EHRENBERG 1840) and $S$. splendida to have typical helictoglossae-like process at the footpole (RUCK \& KocioleK 2004, pl. 23: 10; pl. 29: 14). COCQUYT \& TAYLOR (2015) showed S. ebalensis to have a continuous raphe with a reduced helictoglossa, but a discontinuous raphe with ends at the footpole that formed two reduced helictoglossae separated farther away from the raphe endings (COCQUYT \& TAYLOR 2015, Fig. 5 C-D). Another uncommon feature observed in our new species is the small teeth at the mantle of headpole. CocQuYT et al. (2017) also found similar structures in Surirella chasei Cholnoky (CHOLNOKY 1954) which is diagnosed by the various granules scattered on the entire valve face. More research is needed to understand the morphological diversity of helictoglossae and teeth-shaped structure of Iconella, and its position in the taxonomy of the Surirellales.

Our exploration of tropical areas in China has resulted in the report of several new and endemic species (e.g. Liu et al. 2014a,b, 2016, 2018), indicating the diatom flora is very unique in this region. However, diatom biodiversity is still poorly understood for this area. We expect as further collections are made in the region, and subsequent taxonomic works are carried out, additional new taxa will be described from tropical areas in China.

\section{REFERENCES}

Blanco, S.; Álvarez-Blanco, I.; Cejudo-Figueiras, C.; Godos, I.; BÉCARES, E.; MunOZ, R.; GuZMan, H.O.; VARGas, V.A. \& Soto, R. (2012): New diatom taxa from high-altitude Andean saline lakes. - Diatom 


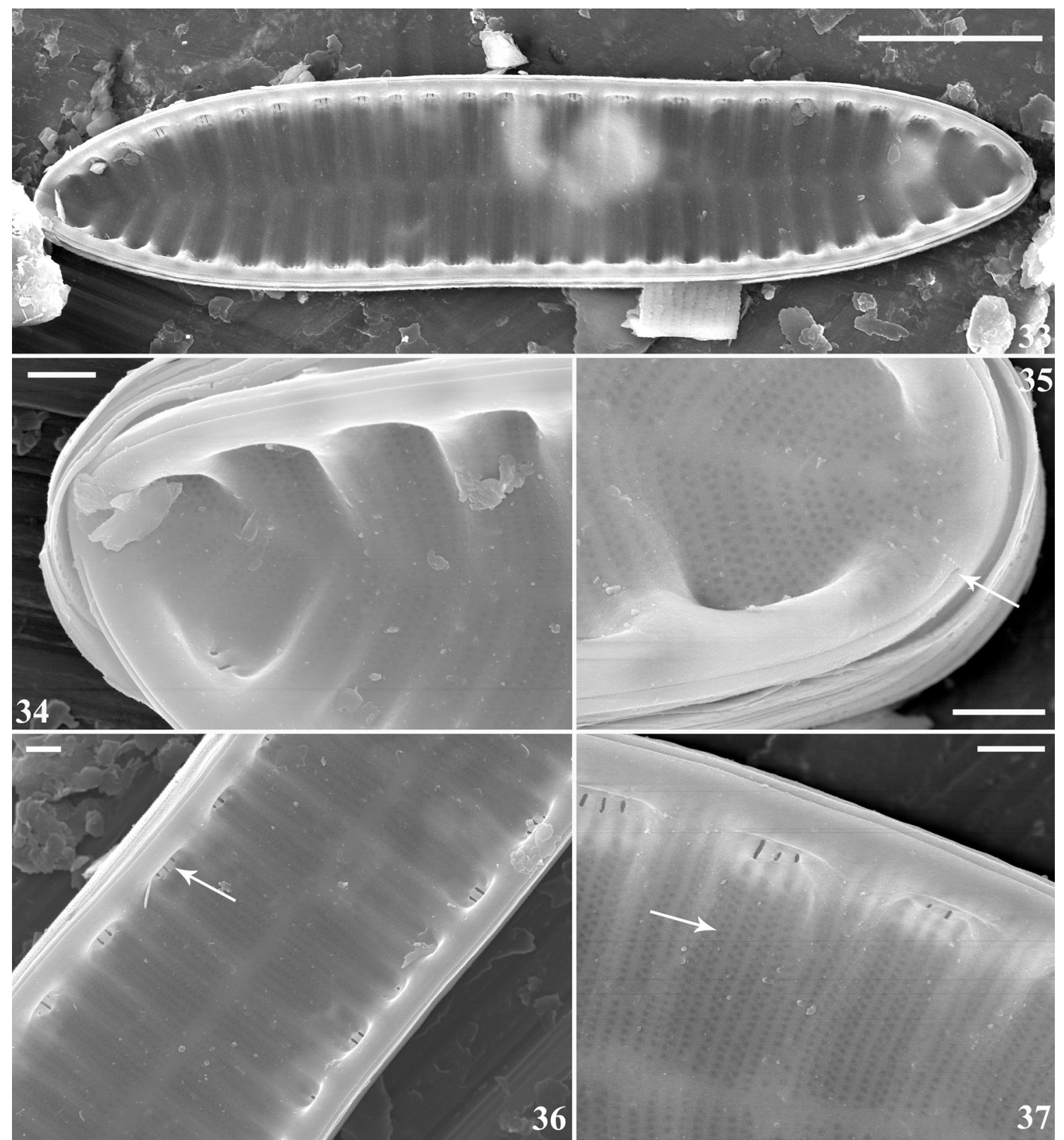

Figs. 33-37. Iconella pseudoconstricta Liu, Jiang, Kociolek et Fan, SEM pictures, external views: (33) whole valve; (34-35) apex of valve, showing the distal raphe ends (white arrow in fig. 35); (36) fenestral bars (white arrow); (37) biseriate striae (white arrow). Scale bar $10 \mu \mathrm{m}$ (33), $1 \mu \mathrm{m}(34-37)$

Research 27: 1-15.

Bramburger, J.; HafFner, G.D.; Hamilton, P.B.; Finz, H. \& Hehanussa, P.E. (2006): An examination of species within the genus Surirella from the Malili lakes, Sulawesi Island, Indonesia, with descriptions of 11 new taxa. - Diatom Research 21: 1-56.

Brindle, M.; Mohan, J.; Beck, C. \& Stone, J.R. (2018): Three novel species of Bacillariophyta (Diatoms) in the genera Surirella and Thalassiosira from Pleistoncene Paleolake Lorenyang ( 2 - 1.6 Ma) Turkana Basin. Phytotaxa 371: 230-240.

Cleve-Euler, A. (1952): Die Diatomeen von Schweden und Finnland. Part V. (Schluss.). - Kongliga Svenska Vetenskaps-Akademiens Handligar, ser. 43: 1-153.

Cholnoky, B.J. (1954): Diatomeen aus Süd-Rhodesien. Portugaliae Acta Biologica ser. B 4: 197-228.
COCQUYT, C. \& JAHN, R. (2005a): Rare Surirella taxa (Bacillariophyta) from East Africa described by Otto Müller: typifications, recombinations, new names, annotations and distributions. - Willdenowia 35: 359-371.

COCQUYT, C. \& JAHN, R. (2005b): Surirella capensis Ehrenberg ex Cocquyt \& R.Jahn, spec. nov., a rare and historical diatom species from South Africa. - Cryptogamie Algologie 26: 149-153.

Cocquyt, C. \& JAHN, R. (2007a): Surirella engleri O. Müller - a study of its types, infraspecific variability and distribution. - Diatom Research 22: 1-16.

Cocquyt, C. \& JAHN, R. (2007b): Surirella fuellebornii (Bacillariophyta) and related taxa: lectotypification and distribution. - Systematics and Geography of Plants 77: 213-228.

CocQuyt, C. \& JAHN, R. (2007c): Taxa related to Surirella 

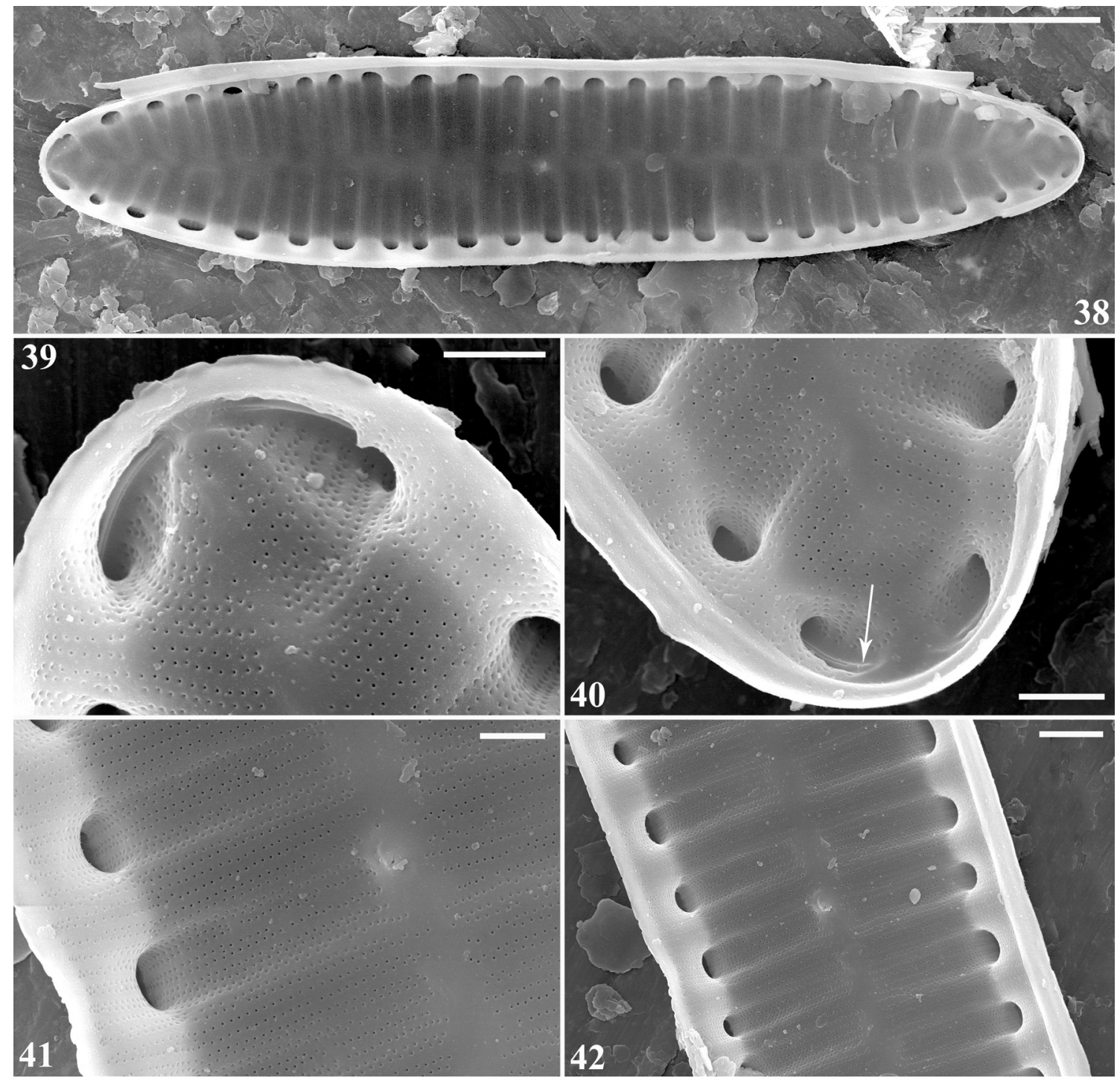

Figs 38-42. Iconella pseudoconstricta Yan Liu, Ziyi Jiang et Kociolek, SEM pictures, internal views: (38) whole valve; (39-40) apices of the same valve, showing the discontinuous distal raphe ends (white arrow in fig. 40); (41) small and round areolar opening; (42) striae discontinuous in the axial area. Scale bar $10 \mu \mathrm{m}(38), 1 \mu \mathrm{m}(39-41), 2 \mu \mathrm{m}(42)$.

ovalis from Tanzania, East Africa: Typification of O. Müller's taxa and description of a new species. Cryptogamie Algologie 28: 107-116.

COCQuYt, C. \& KuSBER, W.H. (2010): Reinvestigation of West African Surirellaceae (Bacillariophyta) described by Foged from Ghana. - Nova Hedwigia 91: 111-136.

Cocquyt, C. \& TAYlor, J.C. (2015): New and interesting Surirella taxa (Surirellaceae, Bacillariophyta) from the Congo Basin (DR Congo). - European Journal of Taxonomy 133: 1-15.

COCQUYT, C.; TAYLOR, J.C. \& KuSBER, W.H. (2017): Reinvestigation of African Surirella taxa (Bacillariophyta) described by B.J. Cholnoky with some remarks on digitization of diatom types. - Fottea 17: 34-56.

EHRENBERG, C.G. (1840): Characteristik von 274 neuen Arten von Infusorien. - Bericht über die zur Bekanntmachung geeigneten Verhandlungen der Königlich-Preussischen Akademie der Wissenschaften zu Berlin 1840: 197-219.

English, J.D. \& Potapova, M.G. (2011): Ontogenetic and interspecific valve shape variation in the Pinnatae group of the genus Surirella and the description of $S$. lacrimula sp. nov. - Diatom Research 25: 1-19.

Gaul, U.; Geissler, U.; Henderson, M.V.; Mahoney, R. \& Reimer, C.W. (1993): Bibliography oof the finestructure of diatom frustules (Bacillariophyceae). - Proceedings of the Academy of Natural Sciences of Philadelphia 144: 69-238.

Henderson, M.V. \& Reimer, C.W. (2003): Bibliography on the fine structure of diatom frustules (Bacillariophyceae). II. Deletioons, Addenda and Corrigenda for Bibliography I.-Diatom Monographs 3: 1-372.

Hustedt, F. (1937-1939): Systematische und ökologische Untersuchungen über die Diatomeen-Flora von Java, Bali und Sumatra nach dem Material der Deutschen Limnologischen Sunda-Expedition. - „Tropische Binnengewässer, Band VII“. Archiv für Hydrobiologie, Supplement, 15: 131-177,187-295,393-506; 16: $1-155,274-394,638-790$.

Hustedt, F. (1965): Neue und wenig bekannte diatomeen. IX. Süßwasserdiatomeen aus Brasilien, insbesondere 


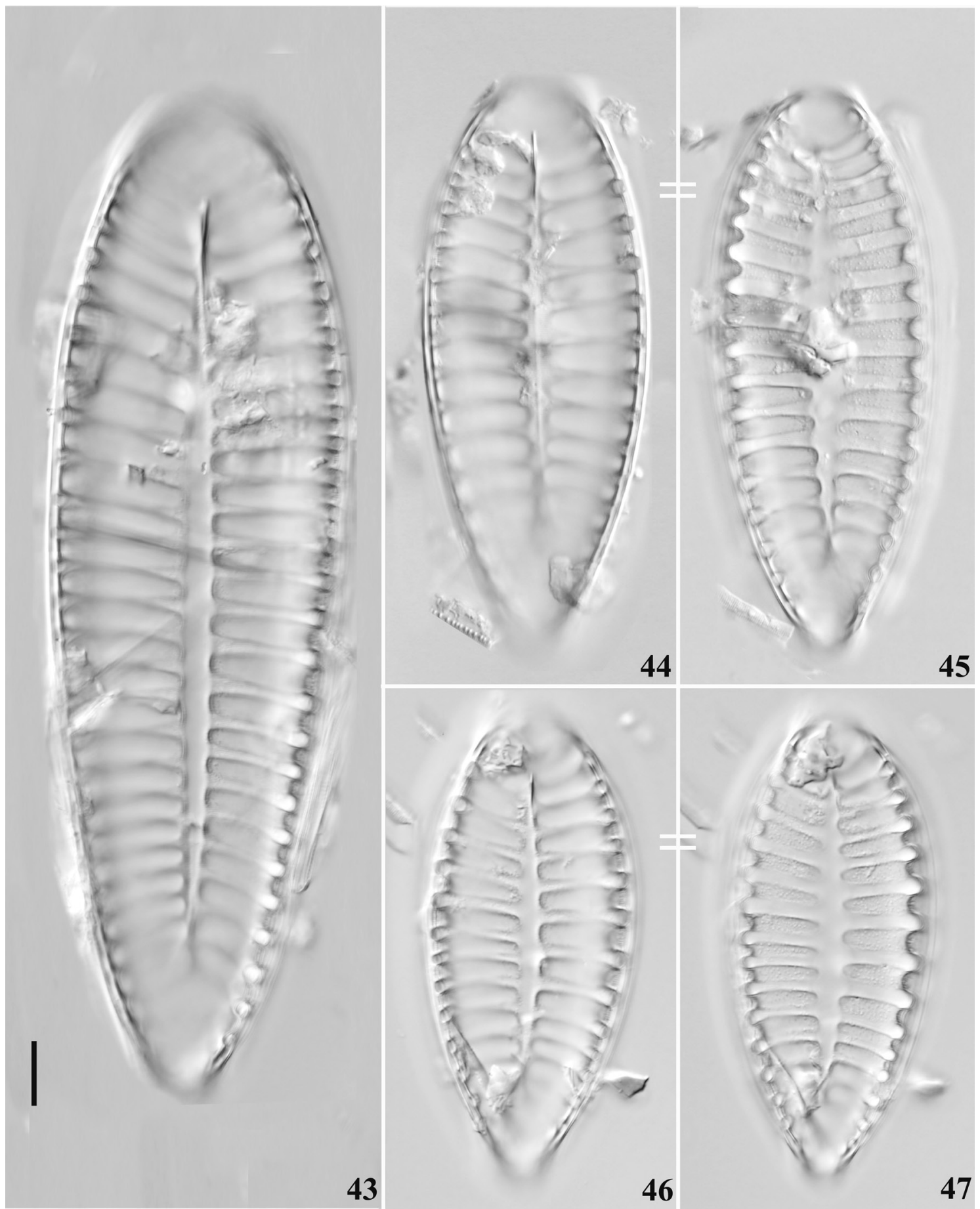

Figs 43-47. Iconella uniformis Yan Liu, Ziyi Jiang et Kociolek, LM pictures, valve view showing the size variation: (44) is of the holotype; (44-45) and (46-47) are each of the same valves at different focal planes. Scale bar $10 \mu \mathrm{m}$.

des Amazonasgebietes. - Internationale Revue der gesamten Hydrobiologie 50: 391-410.

JAHN, R.; KusBer, W.H. \& CoCQuYT, C. (2017): Differentiating Iconella from Surirella (Bacillariophyceae): typifying four Ehrenberg names and a preliminary checklist of the African taxa. - PhytoKeys 82: 73-112.

JuRILJ, A. (1949): Nove Dijatomeje-Surirellaceae-iz Ohridskog Jezera i njihovo filogenetsko znacenje. (New DiatomsSurirellaceae- of Ochrida Lake in Yugoslavia and their phylogenetic significance).-Jugoslavenska Akademija
Znanosti i Umjetnosti, Zagreb (Prirodoslovnih istrazivanja) 24: 171-259.

Kapustin, D. \& Kulikovskiy, M. (2018): Transfer of Stenopterobia and Surirella taxa (Bacillariophyceae) described from the insular Southeast Asia to the genus Iconella. - Nova Hedwigia, Beiheft 147: 237-245.

Karthick, B.; Hamilton, P.B. \& Kociolek, J.P. (2012): Taxonomy and biogeography of some Surirella Turpin (Bacillariophyceae) taxa from Peninsular India. - Nova Hedwigia, Beiheft 141: 81-116. 


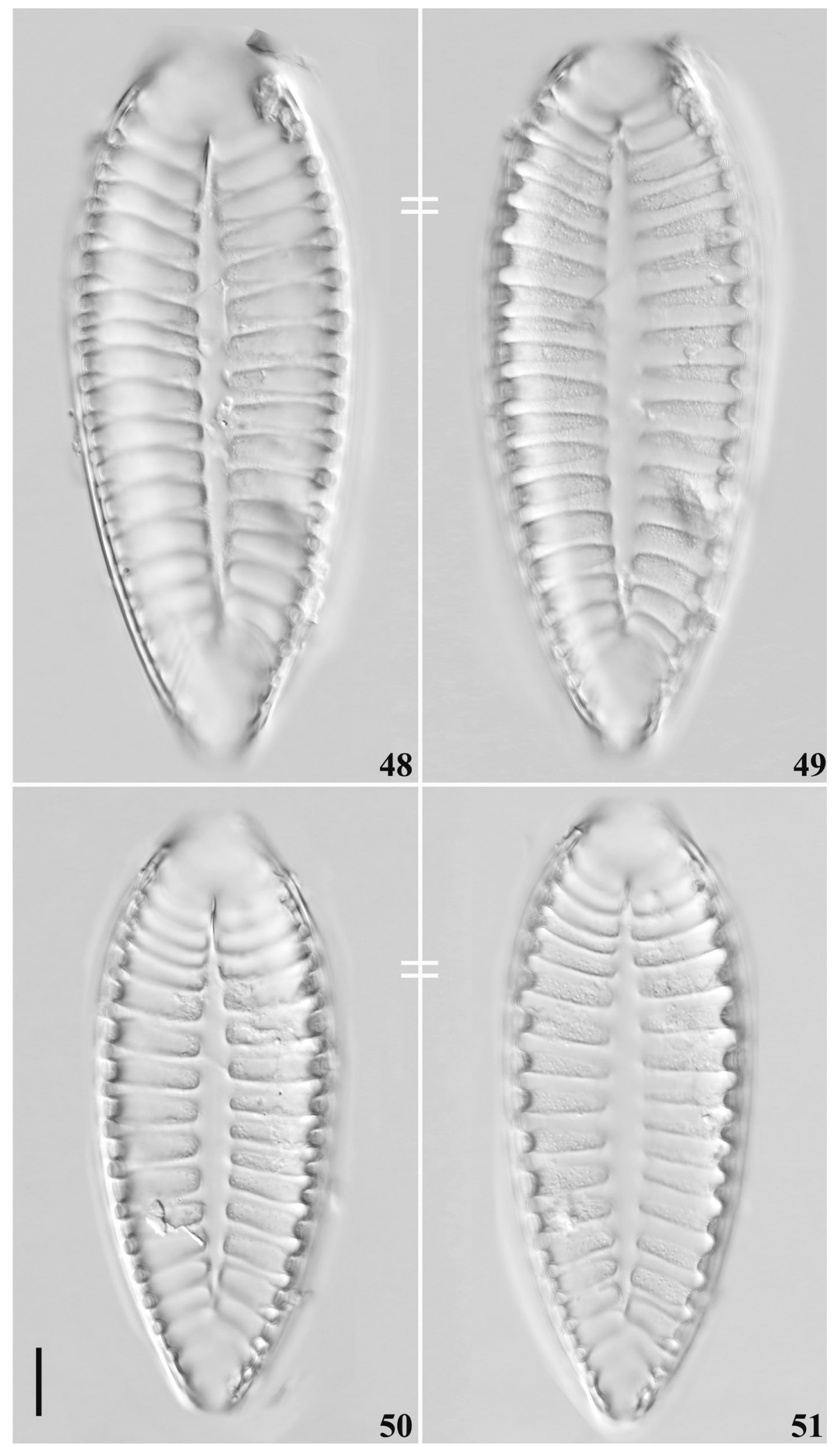

Figs 48-51. Iconella uniformis Yan Liu, Ziyi Jiang et Kociolek, LM pictures, valve view showing the size variation: (48-49) and (50-51) are each of the same valves at different focal planes. Scale bar $10 \mu \mathrm{m}$.

Kociolek, J.P.; Balasubramanian, K.; Blanco, S.; Coste, M.; ECTOR, L.; LiU, Y.; KulikovsKiY, M.; Lundholm, N.; Ludwig, T.; Potapova, M.; Rimet, F.; Sabbe, K.; Sala, S.; SAR, E.; TAYlor, J.; VAn de ViJver, B.; WetZel,
C.E.; Williams, D.M.; WitKowsKi, A.; WitKowsKI, J. (2020): DiatomBase. - Accessed at http://www. diatombase.org on 2020-02-20

Krammer, K. \& Lange-Bertalot, H. (1987): Bacillariophyceae. 

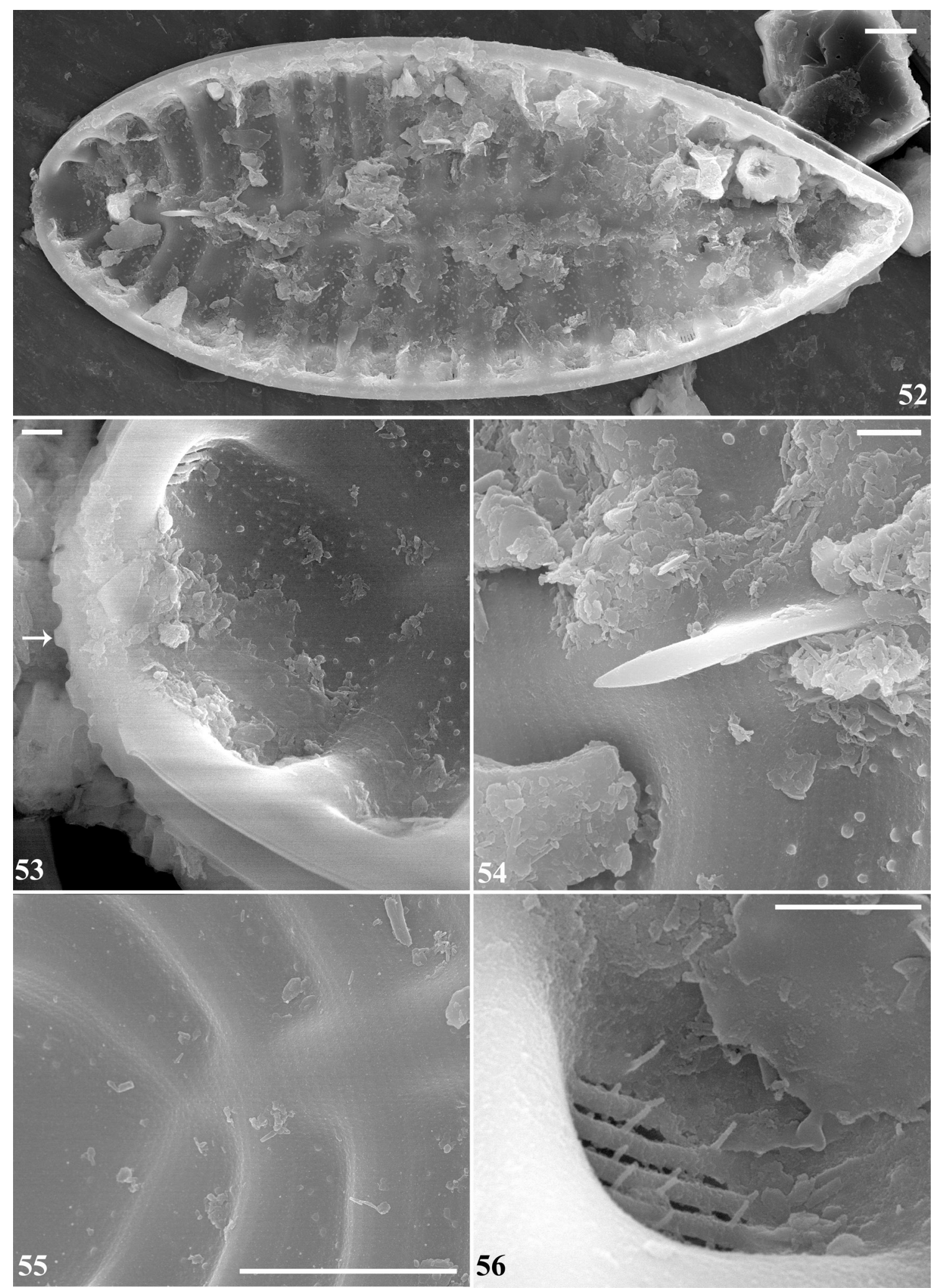

Figs 52-56. Iconella uniformis Yan Liu, Ziyi Jiang et Kociolek, SEM pictures, external views: (52) whole valve; (53) headpole of the valve, showing the distal raphe ends slightly raised, and teeth structure at the mantle of headpole (white arrow); (54) spine in the headpole of axial area; (55) axial area showing the striae continuous in the axial area; (56) a single fenestra, showing the small needle like spine on the fenestral bars. Scale bar $5 \mu \mathrm{m}(52), 1 \mu \mathrm{m}(53-56)$. 

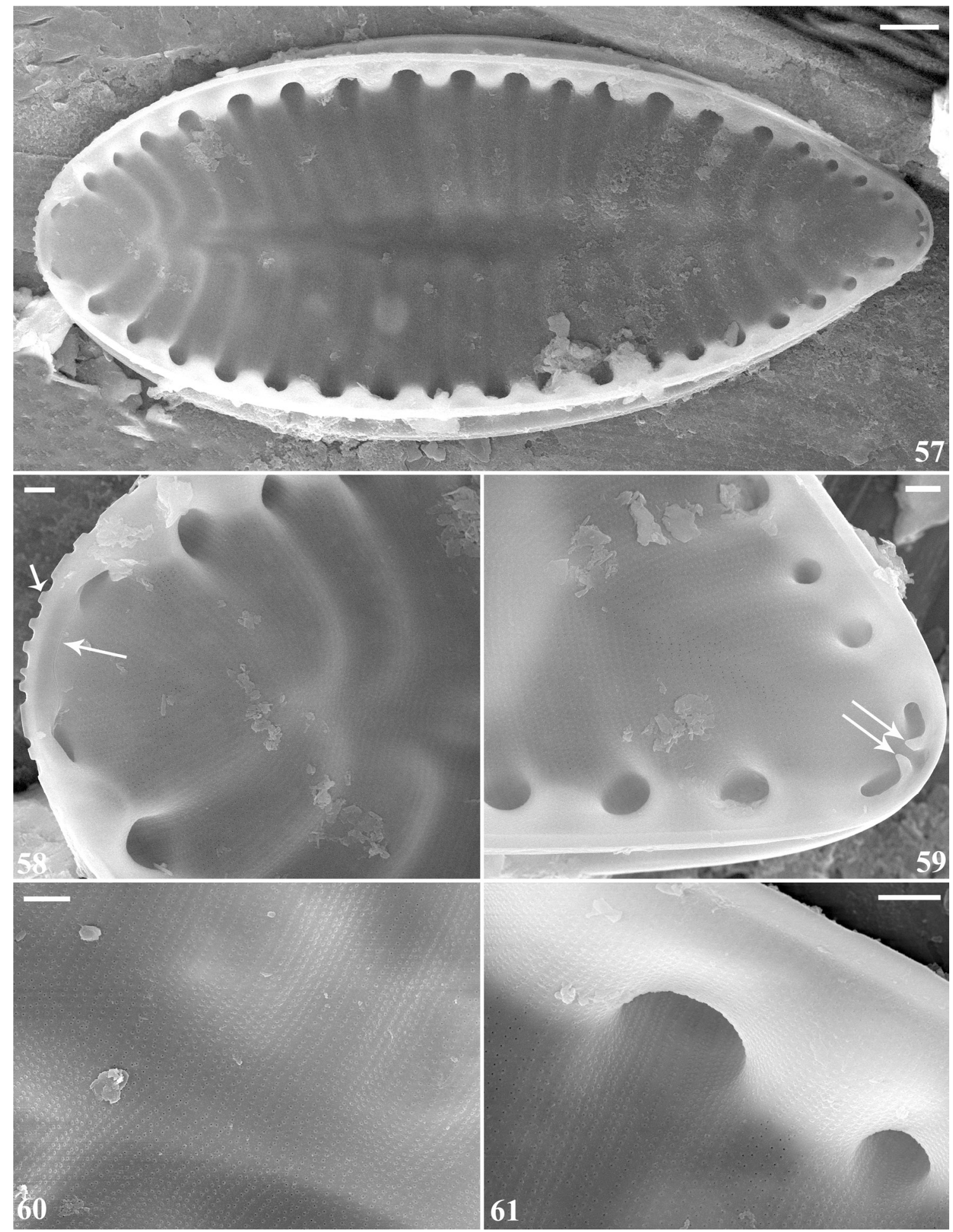

Figs 57-61. Iconella uniformis Yan Liu, Ziyi Jiang et Kociolek, SEM pictures, internal views: (57) whole valve; (58) headpole of the valve, showing the continuous distal raphe ends (white arrow); (59) footpole of the valve, showing the hook-shaped helictoglossae (white arrow); (60) axial area showing the striae continuous in the axial area; (61) valve margin showing the rimmed areolae openings. Scale bar $5 \mu \mathrm{m}(57)$, $1 \mu \mathrm{m}(58-61)$.

2. Teil: Bacillariaceae, Epithemiaceae, Surirellaceae. - In: Ettr, H.; Gerloff, J. \& Heynig, H. (eds): Süsswasserflora von Mitteleuropa. Band 2/2. - 611 pp., Spektrum Akademischer Verlag, Heidelberg.

KüTZING, F.T. (1844): Die Kieselschaligen Bacillarien oder Diatomeen. - 152 pp., W. Köhne, Nordhausen.
LiU, B.; Blanco, S.; Ector, L.; LiU Z.X. \& Ai, J. (2019): Surirella wulingensis sp. nov. and fine structure of S. tientsinensis Skvortzov(Bacillariophyceae) from China. - Fottea 19: 151-162.

LiU, Y.; KocioleK, J. P. \& Fan, Y.W. (2016): Urosolenia and Acanthoceras species frm Hainan Province, China. 
- Phytotaxa 244: 161-173.

LiU, Y.; Kociolek, J.P.; Wang, Q.X. \& FAN, Y.W. (2014a): A new species of Neidium (Bacillariophyceae) and checklist of the genus from China. - Diatom Research 29: $165-173$.

LiU, Y.; KocioleK, J.P.; Wang, Q.X.; Tan, X. \& Fan, Y.W. (2014b): Two new species of monoraphid diatom (Bacillariophyceae) from South of China. - Phytotaxa 188: 031-037.

LiU, Y.; KocioleK, J.P.; Glushchenko, A.; KulikovskiY, M. \& FAN, Y.W. (2018): A new genus of Eunotiales (Bacillariophyta, Bacillariophyceae: Peroniaceae), Sinoperoinia, from Southeast Asia, exhibiting remarkable phenotypic plasticity with regard to the raphe system. - Phycologia 57: 147-158.

LiU, Y.; KocioleK J.P.; LiU, Q.; Tan, X. \& FAn Y.W. (2020): A New Aerophilic Neidium Pfister (Neidiaceae, Bacillariophyta) species from Guangxi Zhuang Autonomous Region, China. - Phytotaxa 432: 171-180.

Mereschrowsky, C. (1906): Diatomées du Tibet. - 40 pp., Imperial Russkoe geograficheskoe obshchestvo, St. Petersburg.

Metzeltin, D. \& Lange-Bertalot, H. (1998): Tropical diatoms of South America I: About 700 predominantly rarely known or new taxa representative of the neotropical flora. - In: LANGE-BERTALOT, H. (ed.): Iconographia Diatomologica. Annotated Diatom Micrographs. -696 pp., A.R.G. Gantner Verlag K.G., Ruggell.

Ruck, E.C.; Nakov, T.; Alverson, A.J. \& Theriot, E.C. (2016): Phylogeny, ecology, morphological evolution, and reclassification of the diatom orders Surirellales and Rhopalodiales. - Molecular Phylogenetics and Evolution 103: 155-171.

Ruck, E. C \& Kociolek, J. P. (2004): Preliminary Phylogeny of the Family Surirellaceae (Bacillariophyceae). - In: Lange-Bertalot, H. \& Kociolek, J.P. (eds): Bibliotheca Diatomologica, Vol. 50. - 236pp, J. Cramer, Berlin \& Stuttgart.

Sala, S.E.; Ramírez, J.J.; Vouilloud, A.A. \& Plata-Díaz, C.Y. (2013): Surirella antioquiensis sp. nov. and $S$. rafaelii sp. nov. (Bacillariophyta) from Colombia. Acta nova 6: $17-35$

SchmidT, A. (1925): Atlas der Diatomaceen-kunde. - VIII( 91), pls. 361-364, O.R. Reisland, Leipzig.

Simonsen, R. (1987): Atlas and catalogue of the diatom types of Friedrich Hustedt. - pp. 1-3, J. Cramer, Berlin \& Stuttgart.

Skvortzow, B.W. (1927): Diatoms from Tientsin North China. - Journal of Botany 65: 102-109.

Skvortzow, B.W. (1928): Diatoms of Khingan, North Manchuria,
China. - Philippine Journal of Science 35: 39-51.

Skvortzow, B.W. (1929a): Alpine Diatoms from Fukien Province, South China. - Philippine Journal of Science 41: 39-49.

Skvortzow, B.W. (1929b): Freshwater Diatoms from Amoy, South China. - The China Journal. Shanghai 2: 40-44,

Skvortzow, B.W. (1930): Diatoms from Dalai-Nor Lake, Eastern Mongolia. - Philippine Journal of Science 41:31-37.

Skvortzow, B.W. (1976): Moss diatoms flora from River Gan in the northern part of Great Khingan Mts, China. With descriptions of a new genera Porosularia gen. nov. from northern and southern China, The Second Part. - Quarterly Journal of the Taiwan Museum 29: 397-439.

Sмiтh, W. (1851): Notes on the Diatomaceae, with descriptions of Britisch species included in the genera Campylodiscus, Surirella, Cymatopleura. - Annals and magazine of natural history, including zoology, botany, and geology 7: 1-14.

TuRPIN, P.J.F. (1828): Observations sur le nouveau Genre Surirella.-Mémoires du muséum d'histoire naturelle, - Paris 16: 361-368.

VAN de ViJver, B.; Cocquyt, C.; De HaAn, M.; Kopalová, K. \& Zidarova, R. (2013): The genus Surirella (Bacillariophyta) in the subAntarctic and maritime Antarctic region. - Diatom Research 28: 93-108.

Van Heurck, H. (1896): A Treatise on the Diatomaceae. Translated by W.E. Baxter. - 558 pp., William Wesley \& Son, London.

Vyverman, W. (1991): Diatoms of Papua New Guinea. - In: LANGe-Bertlaot, H. (ed.): Bibliotheca Diatomologica, Vol. 22. - 224 pp., J. Cramer, Berlin \& Stuttgart.

WANG, Q.X. (2018): Flora algarum cinicarum aquae dulcis (Tomus XXII): Bacillariophyta - Aulonoraphidinales. -166 pp., Science Press, Beijing.

YANG, J.G. (1999): Two new records of genus Surirella in China. - Journal of Anhui Normal University (Natural Science) 22: 1.

You, Q.M. \& WANG, Q.X. (2011): Four new recorded species of Surirellaceae (Bacillariophyta) in China. - Plant Science Journal 29: 260-264.

Zhu, H.Z. \& Chen, J.Y. (2000): Bacillariophyta of the Xizang Plateau. -353 pp., Science Press, Beijing.

(C) Czech Phycological Society (2021)

Received October 26, 2020

Accepted April 15, 2021 